\title{
Inflammatory and Cytotoxic Activities of Abietane Terpenoids from Nepeta bracteata Benth.
}

\author{
Manli Zhang ${ }^{1}$, Meiying Chen ${ }^{2}$, Yong Hou ${ }^{2}$, Congzhao Fan ${ }^{3}$, Hongyan Wei ${ }^{3}$, Leiling Shi ${ }^{3, *}$, Guoxu Ma ${ }^{2}$ \\ and Jing Zhang ${ }^{1, *}$
}

1 College of Chinese Medicine Material, Jilin Agricultural University, Changchun 130118, China; zmlfl1221@163.com

2 Key Laboratory of Bioactive Substances and Resource Utilization of Chinese Herbal Medicine, Institute of Medicinal Plant Development, Peking Union Medical College and Chinese Academy of Medical Sciences, Beijing 100193, China; myc1091@163.com (M.C.); houyong@implad.ac.cn (Y.H.); mgxfl8785@163.com (G.M.)

3 Xinjiang Institute of Chinese and Ethnic Medicine, Urumqi 830002, China; fcz_840701@163.com (C.F.); whywlmq@163.com (H.W.)

* Correspondence: shileiling163@163.com (L.S.); zhangjing4693@jlau.edu.cn (J.Z.); Tel.: +86-136-5991-1138 (L.S.); +86-133-5314-4693 (J.Z.)

check for

updates

Citation: Zhang, M.; Chen, M.; Hou, Y.; Fan, C.; Wei, H.; Shi, L.; Ma, G.;

Zhang, J. Inflammatory and Cytotoxic Activities of Abietane Terpenoids from Nepeta bracteata Benth.. Molecules 2021, 26, 5603. https:// doi.org/10.3390/molecules26185603

Academic Editors: Luisa Tesoriere and Alessandro Attanzio

Received: 10 August 2021

Accepted: 8 September 2021

Published: 15 September 2021

Publisher's Note: MDPI stays neutral with regard to jurisdictional claims in published maps and institutional affiliations.

Copyright: (c) 2021 by the authors. Licensee MDPI, Basel, Switzerland. This article is an open access article distributed under the terms and conditions of the Creative Commons Attribution (CC BY) license (https:// creativecommons.org/licenses/by/ $4.0 /)$.
Abstract: Nepeta bracteata Benth. is used clinically to treat tracheal inflammation, coughs, asthma, colds, fevers, adverse urination, and other symptoms, along with functions in clearing heat and removing dampness. However, there have been few studies characterizing the material basis of its efficacy. Therefore, the aim of this study was to screen for compounds with anti-inflammatory activities in N. bracteata Benth. Using silica gel, ODS C18, and Sephadex LH-20 column chromatography, as well as semipreparative HPLC, 10 compounds were separated from $N$. bracteata Benth. extract, including four new diterpenoids (1-4), one amide alkaloid (5), and five known diterpenoids (6-10). The structures of all the isolates were elucidated by HR-ESI-MS, NMR, and CD analyses. Using lipopolysaccharide (LPS)-stimulated RAW 264.7 cells, we investigated the anti-inflammatory activities of compounds 1-10. It is worth noting that all were able to inhibit nitric oxide (NO) production with $\mathrm{IC}_{50}$ values $<50 \mu \mathrm{M}$ and little effect on RAW 264.7 macrophage viability. Compounds 2 and 4 displayed remarkable inhibition with $\mathrm{IC}_{50}$ values of 19.2 and $18.8 \mu \mathrm{M}$, respectively. Meanwhile, screening on HCT-8 cells demonstrated that compounds $\mathbf{2}$ and $\mathbf{4}$ also had moderate cytotoxic activities with $\mathrm{IC}_{50}$ values of 36.3 and $41.4 \mu \mathrm{M}$, respectively, which is related to their anti-inflammatory effects.

Keywords: terpenoids; Nepeta bracteata Benth.; anti-inflammatory

\section{Introduction}

Inflammation, a common clinical pathological process, is closely related to many diseases such as arthritis, psychosis, cardiovascular and cerebrovascular diseases, and cancer [1-4]. Current anti-inflammatory drugs, such as glucocorticoids, insulin, and the tyrosinase inhibitor kojic acid, are associated with significant side effects [5,6]. Therefore, finding effective anti-inflammatory drugs with fewer side effects is of great importance. Natural products are an important source for new drug discovery; thus, finding and discovering active components from medicinal plants is a hot topic in pharmaceutical chemistry. Nepeta bracteata Benth. belongs to the genus Nepeta of the Lamiaceae family and is mainly distributed in Pakistan, Nepal, Iran, and other countries. It is a folk medicine used by Xinjiang Uyghurs and a medicinal material imported for use in the Xinjiang Uygur hospital, with the Uyghur name "Zufa" [7]. Clinically, it is used to treat tracheal inflammation, coughs, asthma, colds, fevers, adverse urination, and other symptoms [8,9], along with functions in clearing heat and removing dampness. While modern pharmacology has shown that its extract has significant anti-inflammatory activity, no related research has been conducted to characterize its chemical components [10-12]. With the aim of screening for anti-inflammatory active compounds in N. bracteata Benth., a 95\% ethanol extract 
was investigated, and 10 compounds-four new diterpenoids, nepetabrates A-D (1-4), one amide alkaloid, 6-methyl-1,4-oxazocane-5,8-dione (5), and five known diterpenoids, angustanoic acid F (6) [13], 7a-hydroxycallitrisic acid (7) [14], 1-phenanthrenecarboxylic acid (8) [15], angustanoic acid G (9) [16], and jiadifenoic acid K (10) [17]—were obtained (drawn in Figure 1). The structures of the isolates were characterized using comprehensive spectroscopic data analyses. Moreover, the anti-inflammatory activities of the isolated compounds were investigated. In this paper, we describe the structural elucidation of the isolated compounds, as well as their potential anti-inflammatory and cytotoxic effects.

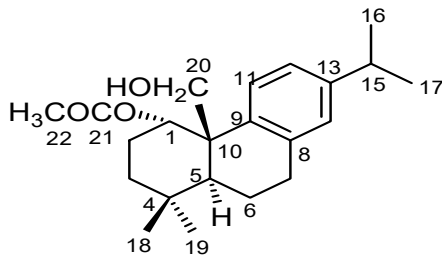

1<smiles>CC(C)c1ccc2c(c1)C(O)CC1(C)C(C)CCC(C)(C=O)C21C</smiles>

2<smiles>CC1=C(C)C2(c3ccc(C(C)C)cc3C(O)C2O)C(C)CC1C</smiles>

3

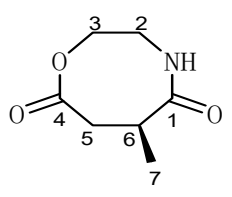

5

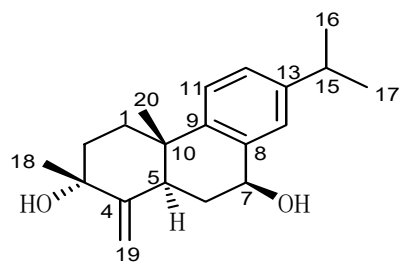

4<smiles>CC(C)c1ccc2c(c1)C(O)C[C@H]1[C@@H]2CCCC1(C)C(C)(CO)CO</smiles><smiles>CC(=O)c1ccc2c(c1)CC[C@H]1[C@@](C)(C(=O)O)CCC[C@@]1(C)c1ccc(C(C)C)cc1C2</smiles>

Figure 1. Structures of compounds 1-10.

\section{Results}

\subsection{Structure Elucidation}

Compound 1 was isolated as a white powder. The molecular formula $\mathrm{C}_{22} \mathrm{H}_{32} \mathrm{O}_{3}$ was established from the HR-ESI-MS spectrum with a positive-ion peak at $m / z[\mathrm{M}+\mathrm{Na}]^{+}$ 367.2215 (calculated 367.2249). The IR spectrum of 1 showed absorptions of hydroxyl $\left(3339 \mathrm{~cm}^{-1}\right)$ and ester carbonyl $\left(1759 \mathrm{~cm}^{-1}\right)$ groups. In the ${ }^{1} \mathrm{H}-\mathrm{NMR}$ spectrum (Table 1$)$, compound 1 showed peaks for three aromatic protons at $\delta_{\mathrm{H}} 7.14(1 \mathrm{H}, \mathrm{d}, J=8.4 \mathrm{~Hz}), 7.17$ $(1 \mathrm{H}, \mathrm{d}, J=8.4 \mathrm{~Hz})$, and $7.22(1 \mathrm{H}, \mathrm{d}, J=1.8 \mathrm{~Hz})$, which suggests the presence of a benzene moiety. Four methyl protons at $\delta_{\mathrm{H}} 1.25(3 \mathrm{H}, \mathrm{d}, J=7.2 \mathrm{~Hz}), 0.97(3 \mathrm{H}, \mathrm{d}, J=7.2 \mathrm{~Hz}), 1.15$ $(3 \mathrm{H}, \mathrm{s})$, and $1.07(1 \mathrm{H}, \mathrm{s})$ indicate the basic diterpenoid skeleton. The downfield methyl signal at $\delta_{\mathrm{H}} 2.07(3 \mathrm{H}, \mathrm{s})$ is evidence for the existence of an acetoxyl group. Meanwhile, three oxygenated protons at $\delta_{\mathrm{H}} 4.82(1 \mathrm{H}, \mathrm{m}), 4.00(1 \mathrm{H}, \mathrm{d}, J=6.6 \mathrm{~Hz})$, and $4.32(1 \mathrm{H}, \mathrm{dd}, J=6.6$, $2.4 \mathrm{~Hz}$ ) suggest the presence of $-\mathrm{OCH}_{2}-$ and $-\mathrm{OCH}$ - groups in the structure, which is in accordance with the ${ }^{13} \mathrm{C}-\mathrm{NMR}$ spectrum showing signals at $\delta_{\mathrm{C}} 68.5,67.3$. The ${ }^{13} \mathrm{C}-\mathrm{NMR}$ spectrum (Table 1) revealed six aromatic carbon signals at $\delta_{\mathrm{C}} 135.9,147.1,124.9,126.9$, 146.8, and 127.9. Aside from these aromatic carbons, the ${ }^{13} \mathrm{C}-\mathrm{NMR}$ also showed five methyl signals at $\delta_{\mathrm{C}} 24.2,13.9,24.8,28.7$, and 19.4, five methylene signals at $\delta_{\mathrm{C}} 36.2,37.9,19.4,27.4$, and 67.3 , three methine signals at $\delta_{\mathrm{C}} 68.5,45.3$, and 33.7 , and two quartus carbon signals at $\delta_{\mathrm{C}} 36.8$ and 38.6. The proton signals were assigned to the corresponding carbons through direct ${ }^{1} \mathrm{H}$ and ${ }^{13} \mathrm{C}$ correlations in the HSQC spectrum. From the ${ }^{1} \mathrm{H}-{ }^{1} \mathrm{H}$ COSY analysis, four substructures (drawn with bold bonds in Figure 2) were established as $\mathrm{H}_{2}-1 / \mathrm{H}_{2}-2 / \mathrm{H}_{2}-3$, 
$\mathrm{H}-5 / \mathrm{H}_{2}-6 / \mathrm{H}_{2}-7, \mathrm{H}-11 / \mathrm{H}-12$, and $\mathrm{H}-15 / \mathrm{H}_{3}-16 / \mathrm{H}_{3}-17$, suggesting that compound 1 has an abietane diterpene skeleton [16]. In the HMBC spectrum (Figure 2), the correlations from $\delta_{\mathrm{H}}$ $4.82(1 \mathrm{H}, \mathrm{m}, \mathrm{H}-1)$ to $\delta_{\mathrm{C}} 171.6$ indicate that the acetoxyl group is attached to $\mathrm{C}-1$. Meanwhile, the HMBC correlations from $\delta_{\mathrm{H}} 4.00(1 \mathrm{H}, \mathrm{d}, J=6.6 \mathrm{~Hz})$ and $4.32(1 \mathrm{H}, \mathrm{dd}, J=6.6,2.4 \mathrm{~Hz})$ to $\mathrm{C}-10\left(\delta_{\mathrm{C}} 38.6\right)$ and $\mathrm{C}-9\left(\delta_{\mathrm{C}} 147.1\right)$ indicate that the angular methyl group at $\mathrm{C}-10$ was further oxidized to a hydroxylmethyl unit. Thus, the planar structure of compound $\mathbf{1}$ was fully elucidated. In the NOESY spectrum, the enhancement between $\mathrm{H}-1$ and $\mathrm{H}_{2}-20, \mathrm{H}-5$, and $\mathrm{H}_{3}-19$ suggests the $\alpha$-orientation of the acetoxyl group at $\mathrm{C}-1$. Considering the identical biosynthetic relationship of abietane diterpenoids, the absolute configuration of $\mathbf{1}$ can be inferred as $1 S, 5 S, 10 S$. The ECD spectra were calculated using density functional theory (DFT) at the APFD/6-311 + g (2d, p) level to further support the deduction (Figure 3). As a result, the structure of compound $\mathbf{1}$ was determined as shown and given the trivial name nepetabrate A.

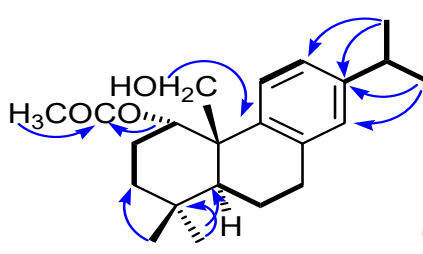

1

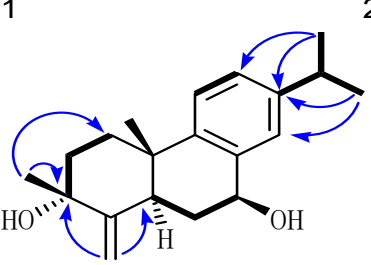

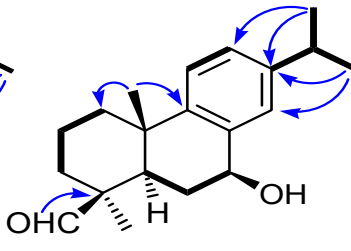

2

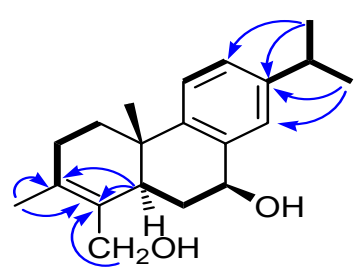

3

Figure 2. Key ${ }^{1} \mathrm{H}-{ }^{1} \mathrm{H}$ COSY (in bolds) and $\mathrm{HMBC}$ (arrows) correlations of compounds 1-5.

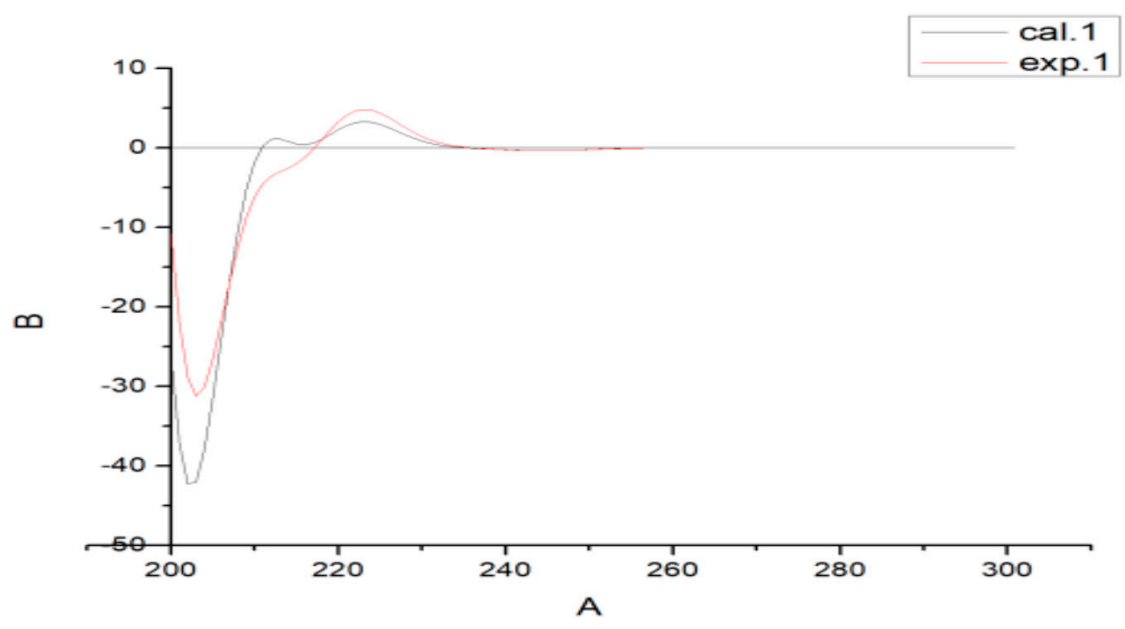

Figure 3. Experimental and calculated ECD spectra of $\mathbf{1}$. 
Table 1. NMR spectral data of $\mathbf{1 - 5}$ (600 MHz for ${ }^{1} \mathrm{H}-\mathrm{NMR}$ and $150 \mathrm{MHz}$ for $\left.{ }^{13} \mathrm{C}-\mathrm{NMR}\right)$.

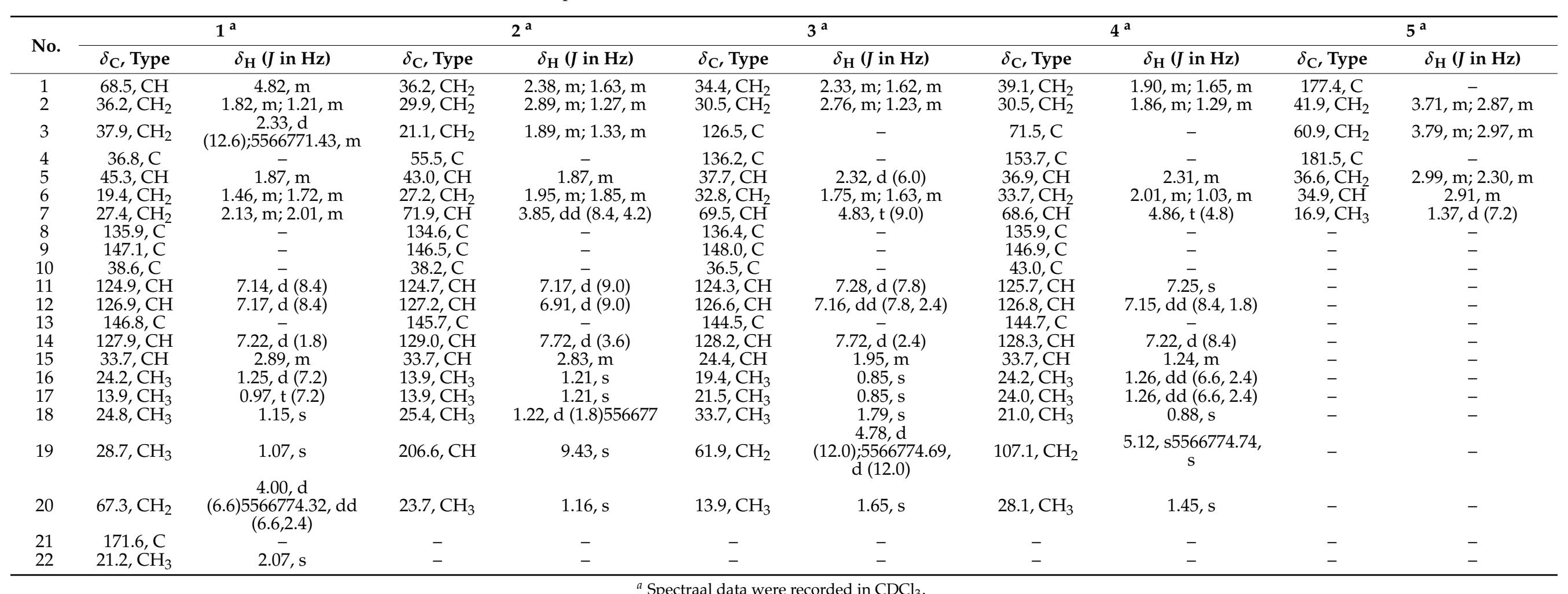

${ }^{a}$ Spectraal data were recorded in $\mathrm{CDCl}_{3}$. 
Compound 2 was obtained as a white powder with its molecular formula assigned as $\mathrm{C}_{20} \mathrm{H}_{28} \mathrm{O}_{2}$ according to the positive HR-ESI-MS peak at $m / z[\mathrm{M}+\mathrm{Na}]^{+} 323.2013$ (calculated 323.2089), exhibiting seven degrees of unsaturation. Through the ${ }^{1} \mathrm{H}$ - and ${ }^{13} \mathrm{C}-\mathrm{NMR}$ spectra, we inferred that the basic mother nucleus of compound 2 was an abietane diterpene, which was further confirmed by the ${ }^{1} \mathrm{H}-{ }^{1} \mathrm{H}$ COSY and HMBC spectra (Figure 2). In fact, the NMR data of compound 2 were similar to those reported for 1-phenanthrenecarboxylic acid, except for an additional aldehyde signal at $\delta_{\mathrm{H}} 9.43(\mathrm{~s}), \delta_{\mathrm{C}} 206.6$, and oxygenated methine carbon at $\delta_{\mathrm{C}} 71.9$ [15]. The presence of the aldehyde group was due to the oxidation of a methyl group at C-19, as supported by the correlations between $\mathrm{H}-19\left(\delta_{\mathrm{H}} 9.43\right)$ and $\mathrm{C}-4$ $\left(\delta_{\mathrm{C}} 55.5\right)$ in the HMBC spectrum. In addition, one hydroxyl group placed at C-7 led to the downfield chemical shift of C-7 $\left(\delta_{C} 71.9\right)$, as confirmed by HMBC correlations. The relative configuration of compound 2 was established by analysis of its NOESY data. The key NOE correlations between $\mathrm{H}-5$ and $\mathrm{H}-7$ and between $\mathrm{H}_{3}-18$ and $\mathrm{H}-19$ supported the $\beta$-orientations of both the aldehyde and the hydroxyl groups. Combined with the experimental and calculated CD curves (Supplementary Materials. Figure S31), the absolute configuration of compound 2 was identified as established and given the trivial name nepetabrate B.

Compound 3, purified as a white powder, has a molecular formula of $\mathrm{C}_{20} \mathrm{H}_{28} \mathrm{O}_{2}$, deduced from the HR-ESI-MS quasimolecular ion at $m / z 323.2021[\mathrm{M}+\mathrm{Na}]^{+}$(calculated 323.2089). The ${ }^{1} \mathrm{H}$ - and ${ }^{13} \mathrm{C}-\mathrm{NMR}$ spectroscopic data (Table 1 ) of $\mathbf{3}$ were similar to those of compound 2, except for the additional hydroxymethyl group at $\delta_{\mathrm{C}} 61.9$ and double bond at $\delta_{\mathrm{C}} 126.5$ and 136.2, indicating that compound 3 is an analogue of compound 2 . In the $\mathrm{HMBC}$ spectrum, the correlations from $\mathrm{H}-5\left(\delta_{\mathrm{H}} 2.32\right)$ to $\mathrm{C}-3\left(\delta_{\mathrm{C}} 126.5\right)$ and $\mathrm{C}-4\left(\delta_{\mathrm{C}} 136.2\right)$, from $\mathrm{H}_{3}-20\left(\delta_{\mathrm{H}} 1.65\right)$ to $\mathrm{C}-4\left(\delta_{\mathrm{C}} 136.2\right)$, and from $\mathrm{H}_{2}-19$ to $\mathrm{C}-3\left(\delta_{\mathrm{C}} 126.5\right)$ (Figure 2$)$ implied a double bond at C-3/C-4, as well as substitutions of its methyl and hydroxymethyl groups. Compound $\mathbf{3}$ is the product of methyl migration and dehydrogenation of compound 2, which is not common in abietane diterpenes. The similar NOESY spectra of compounds 2 and 3 suggest their identical relative configurations. Together with the experimental and calculated CD curves (Supplementary Materials, Figure S32), compound 3 was elucidated as nepetabrate $C$.

Compound 4 was obtained as a white powder with a molecular formula of $\mathrm{C}_{20} \mathrm{H}_{28} \mathrm{O}_{2}$ based on the positive-ion HR-ESI-MS peak at $m / z 323.2023[\mathrm{M}+\mathrm{Na}]^{+}$(calculated 323.2089). The ${ }^{1} \mathrm{H}$ - and ${ }^{13} \mathrm{C}$-NMR spectroscopic data (Table 1 ) of 4 were quite similar to those of 3 , except for the appearance of olefin protons at $\delta_{\mathrm{H}} 5.12$ and 4.74 and the disappearance of two oxygenated protons in 4 . Further analysis of the NMR data of compound 4 revealed the presence of an outer ring double bond at C-4/19, which was confirmed by the HMBC correlations from $\mathrm{H}-19\left(\delta_{\mathrm{H}} 4.78,4.69\right)$ to $\mathrm{C}-3\left(\delta_{\mathrm{C}} 71.5\right)$ and $\mathrm{C}-5\left(\delta_{\mathrm{C}} 36.9\right)$. Furthermore, the quartus carbon of $\mathrm{C}-3\left(\delta_{\mathrm{C}} 71.5\right)$, together with the molecular formula above, implies the presence of hydroxyl substitution in the structure. The HMBC correlations from $\mathrm{H}_{3}-18\left(\delta_{\mathrm{H}}\right.$ $0.88)$ to $\delta_{\mathrm{C}} 71.5$ reveal the location of $\mathrm{CH}_{3}-18$ at $\mathrm{C}-3$. The key NOESY enhancements between $\mathrm{H}-5$ and $\mathrm{H}-7$ and between $\mathrm{CH}_{3}-18$ and $\mathrm{CH}_{3}-20$ revealed the opposing configurations of 3-OH and 7-OH. The absolute configuration was determined by DFT calculations of the ECD spectra (Supplementary Materials, Figure S33), which confirmed the $3 R, 5 R, 7 S$, and $10 S$ configurations. Thus, compound 4 was assigned as nepetabrate D.

Compound 5 was obtained as a yellow amorphous powder, with its molecular formula assigned as $\mathrm{C}_{7} \mathrm{H}_{11} \mathrm{NO}_{3}$ on the basis of its positive HR-ESI-MS $(\mathrm{m} / z \text { 180.0723 [M }+\mathrm{Na}]^{+}$ (calculated 180.0739), implying three degrees of unsaturation. The IR spectrum of 5 showed carbonyl $\left(1724 \mathrm{~cm}^{-1}\right)$ and methyl $\left(2938,2924 \mathrm{~cm}^{-1}\right)$ groups. In the ${ }^{1} \mathrm{H}-\mathrm{NMR}$ spectrum (Table 1), compound 5 showed four downfield chemical signals at $\delta_{\mathrm{H}} 3.79,2.97,2.99$, and 2.39 , one methyl proton at $\delta_{\mathrm{H}} 1.37(3 \mathrm{H}, \mathrm{d}, J=7.2 \mathrm{~Hz})$, and one methine proton at $\delta_{\mathrm{H}} 2.91$ $(1 \mathrm{H}, \mathrm{m})$. The ${ }^{13} \mathrm{C}-\mathrm{NMR}$ spectrum (Table 1$)$ revealed the presence of two carbonyl groups at $\delta_{\mathrm{C}} 177.4$ and 181.5 , three methylene carbons at $\delta_{\mathrm{C}} 41.9,60.9$, and 36.6 , one methine carbon at $\delta_{\mathrm{C}} 34.9$, and one methyl carbon at $\delta_{\mathrm{C}} 16.9$. Analysis of the ${ }^{1} \mathrm{H}-{ }^{1} \mathrm{H}$ COSY correlations revealed the presence of two partial structures of $-\left(\mathrm{CH}_{2}\right)_{2}-$ and $-\mathrm{CH}_{2}-(\mathrm{CH}) \mathrm{CH}_{3}-$, as shown 
in Figure 2. In the HMBC spectrum, the correlations from $\delta_{\mathrm{H}} 3.79,2.97(2 \mathrm{H}, \mathrm{m}, \mathrm{H}-3)$ and $\delta_{\mathrm{H}} 2.99(1 \mathrm{H}, \mathrm{H}-5 \mathrm{a}), 2.39(1 \mathrm{H}, \mathrm{dd}, J=4.2,4.2 \mathrm{~Hz}, \mathrm{H}-5 \mathrm{~b})$ to $\delta_{\mathrm{C}} 181.5(\mathrm{C}-4), \delta_{\mathrm{H}} 3.71,2.87$ $(2 \mathrm{H}, \mathrm{m}, \mathrm{H}-2)$, and $\delta_{\mathrm{H}} 1.37\left(3 \mathrm{H}, \mathrm{d}, J=7.2 \mathrm{~Hz}, \mathrm{H}_{3}-7\right)$ to $\delta_{\mathrm{C}} 177.4(\mathrm{C}-1)$ demonstrate that the two fragments were connected through ester carbonyl carbons. Further analysis of the carbon signal of C-2 $\left(\delta_{\mathrm{C}} 41.9\right)$ and the molecular formula above confirmed an amide unit between C-2 and C-6. The absolute configuration of C-6 was assigned as $S$ on the basis of a comparison of its experimental and calculated CD curves. From all the above data, compound 5 was established as shown and named 6-methyl-1,4-oxazocane-5,8-dione.

\subsection{Bioactive Activity}

The anti-inflammatory activities of compounds 1-10 were evaluated in RAW 264.7 macrophages with aspirin as the positive control [18,19]. As shown in Table 2, in the RAW 264.7 macrophage viability test, all compounds showed mild or inavtive effects for RAW 264.7 macrophages. On the contrary, compounds 1-10 displayed different degrees of anti-inflammatory activity against RAW 264.7 macrophages, with $\mathrm{IC}_{50}$ values ranging from 18.0 to $46.3 \mu \mathrm{M}$. Among the abietane diterpenes, compounds 2 and 4 displayed the most anti-inflammatory activity with $\mathrm{IC}_{50}$ values of 19.2 and $18.8 \mu \mathrm{M}$, respectively. Compound 5, as an amide alkaloid, also showed a remarkable inhibition effect with an $\mathrm{IC}_{50}$ value of $18.0 \mu \mathrm{M}$, as compared with the $\mathrm{IC}_{50}$ values of 15.9 for the positive control, aspirin. Cytotoxic testing on HCT-8 cells showed that compounds 2 and $\mathbf{4}$ had moderate activity with $\mathrm{IC}_{50}$ values of 36.3 and $41.4 \mu \mathrm{M}$, respectively, while the other compounds were inactive or mildly active when compared with the positive control, adriamycin.

Table 2. Anti-inflammatory and cytotoxic activities of the isolated compounds.

\begin{tabular}{cccc}
\hline \multirow{2}{*}{ Compounds } & Cell Survival Rate (\%) & \multicolumn{2}{c}{ IC $_{\mathbf{5 0}}(\boldsymbol{\mu M})$} \\
\cline { 2 - 4 } & RAW 264.7 Macrophages & RAW 264.7 Macrophages & HCT-8 \\
\hline $\mathbf{1}$ & $97.93 \pm 0.26$ & $38.2 \pm 1.15^{\text {a }}$ & $>50$ \\
$\mathbf{2}$ & $88.26 \pm 0.32$ & $19.2 \pm 1.25$ & $36.3 \pm 1.10$ \\
$\mathbf{3}$ & $99.84 \pm 0.21$ & $22.3 \pm 1.26$ & $>50$ \\
$\mathbf{4}$ & $92.21 \pm 0.19$ & $18.8 \pm 0.75$ & $41.4 \pm 0.91$ \\
$\mathbf{5}$ & $99.21 \pm 0.15$ & $18.0 \pm 1.13$ & $>50$ \\
$\mathbf{6}$ & $99.89 \pm 0.13$ & $36.2 \pm 1.21$ & $>50$ \\
$\mathbf{7}$ & $98.75 \pm 0.45$ & $37.1 \pm 0.81$ & $>50$ \\
$\mathbf{8}$ & $99.12 \pm 0.28$ & $37.5 \pm 0.92$ & $>50$ \\
$\mathbf{9}$ & $98.26 \pm 0.18$ & $42.3 \pm 0.56$ & $>50$ \\
$\mathbf{1 0}$ & $98.75 \pm 0.20$ & $46.3 \pm 1.02$ & $>50$ \\
Aspirin ${ }^{\mathrm{b}}$ & & $15.9 \pm 0.38$ & $1.78 \pm 0.14$ \\
Adriamycin & & & \\
DMEM (PBS) $^{\mathrm{c}}$ & 100.00 & & \\
${ }^{\text {a }}$ Values are means \pm SD of triplicate experiments. $^{\mathrm{b}}$ Positive control substance. ${ }^{\mathrm{c}}$ Negative control substance.
\end{tabular}

\section{Discussion}

Although Nepeta bracteata Benth. is widely used clinically and has promising curative effects, there are few studies about this medicinal plant. Previous research found that $N$. bracteata Benth. has certain free-radical-scavenging ability and an anti-inflammatory effect in vitro, and its alcohol extract displayed certain DPPH free-radical-scavenging ability, providing a theoretical basis for further research $[20,21]$. Therefore, we first investigated the active substances of $N$. bracteate Benth. and obtained nine abietane diterpenoids including four new ones, nepetabrates A-D (1-4), and one new amide alkaloid (5). Compared with previous studies, we explored the anti-inflammatory activities of compounds 1-10 on RAW 264.7 macrophages cells. The cell viability of the RAW 264.7 macrophages experiment displayed that all the isolated compounds had mild toxicity to cells at $50 \mu \mathrm{M}$. The antiinflammatory activity test showed that all the abietane diterpenoids displayed different degrees of inhibition effect. Among them, compounds 2 and 4 displayed the greatest antiinflammatory activities with $\mathrm{IC}_{50}$ values 19.2 and $18.8 \mu \mathrm{M}$, as well as moderate cytotoxic 
activities with $\mathrm{IC}_{50}$ values of 36.3 and $41.4 \mu \mathrm{M}$, further proving the correlation between inflammation and cancer. Morever, the results also showed that compound 5 had significant anti-inflammatory activity but had no significant advantage over diterpenes. Accordingly, we believe that diterpenes represent the material basis for the plant to exert its clinical anti-inflammatory effect, which deserves further study.

\section{Materials and Methods}

\subsection{General Experimental Procedures}

Optical rotation data were measured using a Perkin-Elmer 341 digital polarimeter (PerkinElmer, Norwalk, OH, USA). UV (1.0 mg of sample was dissolved in $3 \mathrm{~mL}$ of chromatographic grade methanol for each sample) and IR (1.0 mg of sample was pressed in $\mathrm{KBr}$ for each sample) spectral data were recorded on Shimadzu UV2550 and FTIR-8400S spectrometers (Shimadzu, Kyoto, Japan). CD spectra were obtained using a JASCO J-815 spectropolarimeter. NMR spectra were obtained using a Bruker AV III 600 NMR spectrometer with chemical shift values presented as $\delta$ values using TMS as the internal standard (samples dissolved in an appropriate amount ofdeuterated chloroform). HR-ESI-MS was performed using an LTQ-Orbitrap XL spectrometer (Thermo Fisher Scientific, Boston, MA, USA); samples were dissolved in chromatographic methanol and treated through a membrane, single pump. Colurmn chromatography (CC) was performed using silica gel (100-200 and 200-300 mesh, Qingdao Marine Chemical Plant, Qingdao, China). Semipreparative HPLC was performed using an HPLC PUMP K-501, LC3000 high-performance liquid chromatograph (Beijing Tong Heng Innovation Technology Co., Ltd, Beijing, China), and Kromasil 100-5C18, $250 \times 10 \mathrm{~mm}$, E108850. Precoated silica gel GF 254 plates (Zhi Fu Huang Wu Pilot Plant of Silica Gel Development, Yantai, China) were used for TLC. All solvents used (petroleum ether, ethyl acetate, dichloromethane, methanol (analytical grade and chromatographic grade), and deuterated chloroform) were of analytical grade (Beijing Chemical Plant, Beijing, China).

\subsection{Plant Material}

Nepeta bracteata Benth. was purchased from Xinjiang Uygur hospital (Urumqi, China) and identified as Nepeta bracteata Benth. by Professor Leiling Shi. A voucher specimen (M20191025) was deposited at the Medical Laboratory of Xinjiang Institute of Chinese and Ethnic Medicine (Urumqi, China).

\subsection{Isolation and Purification of Compounds $\mathbf{1}-\mathbf{1 0}$}

The aerial part of Nepeta bracteata Benth. $(6.0 \mathrm{~kg})$ was soaked in ethanol at room temperature $(3 \times 40 \mathrm{~L}, 3 \mathrm{~h}$ each time) and extracted three times under reflux. Removal of the ethanol under reduced pressure yielded the ethanol extract $(437.0 \mathrm{~g})$. The ethanol extract was dissolved in water and successively extracted with petroleum ether $(3 \times 1000 \mathrm{~mL})$, dichloromethane $(3 \times 1000 \mathrm{~mL})$, and ethyl acetate $(3 \times 1000 \mathrm{~mL})$. The petroleum fraction $(134.8 \mathrm{~g})$ was subjected to CC $(12.0 \mathrm{~cm} \times 40.0 \mathrm{~cm}, 300.0 \mathrm{~g})$ over a silica gel (100-200 mesh), eluting with a stepwise gradient of petroleum ether/EtOAC (from 1:0 to 0:1; i.e., 1:0, 100:1, $50: 1,25: 1,8: 1,5: 1,1: 1$, and $0: 1, v / v)$ to yield fractions A-H. Fr.F was subjected to CC $(5.0 \mathrm{~cm} \times 15.0 \mathrm{~cm}, 70.0 \mathrm{~g})$ over a silica gel (100-200 mesh), eluting with a stepwise gradient of petroleum ether/EtOAC (from 20:1 to 1:1; i.e., 20:1, 10:1, 3:1, and 1:1, $v / v$ ) to yield four fractions (Fr.F 1-4). Fr.F 3 was subjected to CC $(3.0 \mathrm{~cm} \times 20.0 \mathrm{~cm}, 65.0 \mathrm{~g})$ over a silica gel (200-300 mesh), eluting with a stepwise gradient of petroleum ether/EtOAC (from 10:1 to 3:1; i.e., 10:1, 5:1, and 3:1, v/v) to yield three fractions (Fr.F 3-1-3). Fr.F 3-2 was purified using semi-preparative $\mathrm{HPLC}$ with $\mathrm{MeOH} / \mathrm{H}_{2} \mathrm{O}(90: 10, v / v)$ as the mobile phase to yield compound 1 (9.0 mg, $\left.t_{R}=42.4 \mathrm{~min}\right)$. Fr.F 3-3 was purified using semi-preparative HPLC of $\mathrm{MeOH} / \mathrm{H}_{2} \mathrm{O}(85: 15, v / v)$ as the mobile phase to yield compounds $2\left(5.2 \mathrm{mg}, \mathrm{t}_{\mathrm{R}}=27.0 \mathrm{~min}\right)$ and $3\left(9.2 \mathrm{mg}, \mathrm{t}_{\mathrm{R}}=28.6 \mathrm{~min}\right)$. Fr.H was subjected to $C C(4.0 \mathrm{~cm} \times 15.0 \mathrm{~cm}, 30.0 \mathrm{~g})$ over a silica gel (100-200 mesh), eluting with a stepwise gradient of petroleum ether/EtOAC (from 15:1 to 1:1; i.e., 15:1, 5:1, 3:1 and 1:1, v/v) to yield four fractions ( Fr.H 1-4 ). Fr.F 3 was 
subjected to CC $(3.0 \mathrm{~cm} \times 20.0 \mathrm{~cm}, 70.0 \mathrm{~g})$ over a silica gel (200-300 mesh), eluting with a stepwise gradient of petroleum ether/EtOAC (from 4:1 to 1:1; i.e., 4:1, 2:1, and 1:1, v/v) to yield three fractions (Fr.H 3-1-3). Fr.F 3-3 was purified by semi-preparative HPLC of $\mathrm{MeOH} / \mathrm{H}_{2} \mathrm{O}(85: 15, v / v)$ as the mobile phase to yield compound $4\left(3.2 \mathrm{mg}, \mathrm{t}_{\mathrm{R}}=25.6 \mathrm{~min}\right)$. The dichloromethane fraction $(67.4 \mathrm{~g})$ was subjected to CC $(8.0 \mathrm{~cm} \times 40.0 \mathrm{~cm}, 240.0 \mathrm{~g})$ over a silica gel (100-200 mesh), eluting with a stepwise gradient of $\mathrm{CH}_{2} \mathrm{Cl}_{2} / \mathrm{MeOH}$ (from 1:0 to $0: 1$; i.e., $1: 0,100: 1,50: 1,30: 1,20: 1,5: 1,1: 1$, and $0: 1, v / v$ ) to yield fractions I-O. Fr.I was subjected to CC $(8.0 \mathrm{~cm} \times 15.0 \mathrm{~cm}, 105.0 \mathrm{~g})$ over a silica gel (100-200 mesh), eluting with a stepwise gradient of petroleum ether/EtOAC (from 15:1 to 1:2; i.e., 15:1, 8:1, 4:1, 2:1, $1: 1$, and $1: 2, v / v$ ) to yield six fractions (Fr.I 1-6). Fr.I 3 was isolated through ODS MPLC elution with $\mathrm{MeOH} / \mathrm{H}_{2} \mathrm{O}$ (50:50, 70:30, 90:10, and 100:0, $\left.v / v\right)$, and purified using semipreparative HPLC to give compounds $6\left(2.0 \mathrm{mg}, \mathrm{t}_{\mathrm{R}}=23.2 \mathrm{~min}\right), 7\left(2.3 \mathrm{mg}, \mathrm{t}_{\mathrm{R}}=26.4 \mathrm{~min}\right)$, and $8\left(1.4 \mathrm{mg}, \mathrm{t}_{\mathrm{R}}=12.7 \mathrm{~min}\right)$. Fr.J was subjected to $C \mathrm{C}(6.0 \mathrm{~cm} \times 20.0 \mathrm{~cm}, 70.0 \mathrm{~g})$ over a silica gel (100-200 mesh), eluting with a stepwise gradient of petroleum ether/EtOAC (from 15:1 to 1:2; i.e., 15:1, 8:1, 4:1, 2:1, 1:1, and 1:2 v/v) to yield six fractions (Fr.J 1-6). Fr.J 2 was purified by semi-preparative HPLC of $\mathrm{MeOH} / \mathrm{H}_{2} \mathrm{O}(85: 15, v / v)$ as the mobile phase to yield compounds $\mathbf{9}\left(3.6 \mathrm{mg}, \mathrm{t}_{\mathrm{R}}=15.9 \mathrm{~min}\right)$ and $\mathbf{1 0}\left(1.4 \mathrm{mg}, \mathrm{t}_{\mathrm{R}}=19.3 \mathrm{~min}\right)$. Fr.J 6 was purified by semi-preparative $\mathrm{HPLC}$ of $\mathrm{MeOH} / \mathrm{H}_{2} \mathrm{O}(38: 62, v / v)$ as the mobile phase to yield compound $5\left(3.6 \mathrm{mg}, \mathrm{t}_{\mathrm{R}}=9.5 \mathrm{~min}\right)$.

\subsection{Characterization of Compounds $\mathbf{1}-\mathbf{5}$}

Nepetabrate A (1), white powder (MeOH); UV (MeOH) $\lambda_{\max }(\log \varepsilon) 291$ (3.52) nm; IR (film) $v_{\max } 3339,2962,2871,1759,1467,1213,1144 \mathrm{~cm}^{-1} ;{ }^{1} \mathrm{H}-$ and ${ }^{13} \mathrm{C}-\mathrm{NMR}$ data $\left(\mathrm{CDCl}_{3}\right)$, see Table 1; HR-ESI-MS $m / z$ 367.2215 [M + Na] ${ }^{+}$(calculated 367.2249, $\mathrm{C}_{22} \mathrm{H}_{32} \mathrm{O}_{3}$ ).

Nepetabrate B (2), white powder (MeOH); UV (MeOH) $\lambda_{\max }(\log \varepsilon) 294$ (3.76) nm; IR (film) $v_{\max } 3338,2994,2936,2872,1460,1221,1099 \mathrm{~cm}^{-1} ;{ }^{1} \mathrm{H}$ - and ${ }^{13} \mathrm{C}-\mathrm{NMR}$ data $\left(\mathrm{CDCl}_{3}\right)$, see Table 1; HR-ESI-MS $m / z 323.2013[\mathrm{M}+\mathrm{Na}]^{+}$(calculated 323.2089, $\mathrm{C}_{20} \mathrm{H}_{28} \mathrm{O}_{2}$ ).

Nepetabrate C (3), white powder (MeOH); UV (MeOH) $\lambda_{\max }(\log \varepsilon) 292$ (3.93) nm; IR (film) $v_{\max } 3342,2958,2875,1456,1230,1138 \mathrm{~cm}^{-1} ;{ }^{1} \mathrm{H}$ - and ${ }^{13} \mathrm{C}$-NMR data $\left(\mathrm{CDCl}_{3}\right)$, see Table 1; HR-ESI-MS $m / z$ 323.2021 [M + Na] ${ }^{+}$(calculated 323.2089, $\mathrm{C}_{20} \mathrm{H}_{28} \mathrm{O}_{2}$ ).

Nepetabrate D (4), white powder $(\mathrm{MeOH})$; UV $(\mathrm{MeOH}) \lambda_{\max }(\log \varepsilon) 294$ (3.53) nm; IR (film) $v_{\max } 3351,2940,2866,1445,1227,1115 \mathrm{~cm}^{-1} ;{ }^{1} \mathrm{H}$ - and ${ }^{13} \mathrm{C}-\mathrm{NMR}$ data $\left(\mathrm{CDCl}_{3}\right)$, see Table 1; HR-ESI-MS $m / z 323.2023$ [M + Na] ${ }^{+}$(calculated 323.2089, $\mathrm{C}_{20} \mathrm{H}_{28} \mathrm{O}_{2}$ ).

6-Methyl-1,4-oxazocane-5,8-dione (5), yellow amorphous powder (MeOH); $\mathrm{UV}(\mathrm{MeOH})$ $\lambda_{\max }(\log \varepsilon) 291(3.76) \mathrm{nm}$; IR (film) $v_{\max } 3350,2938,2874,1724 \mathrm{~cm}^{-1} ;{ }^{1} \mathrm{H}$ - and ${ }^{13} \mathrm{C}-\mathrm{NMR}$ data $\left(\mathrm{CDCl}_{3}\right.$ ), see Table 1 ; HR-ESI-MS $m / z 180.0723[\mathrm{M}+\mathrm{Na}]^{+}$(calculated 180.0739, $\mathrm{C}_{7} \mathrm{H}_{11} \mathrm{NO}_{3}$ ).

\subsection{RAW 264.7 Macrophage Viability Test}

The MTT colorimetric method was used to detect the effect of compounds 1-10 on the viability of RAW 264.7 macrophages. The RAW 264.7 macrophages in the logarithmic growth phase were digested with trypsin to prepare a single-cell suspension, which was seeded in a 96-well plate at a density of $1 \times 10^{4}$ cells per well and cultured in a $5 \% \mathrm{CO}_{2}$ incubator for $24 \mathrm{~h}$ at $37^{\circ} \mathrm{C}$, before discarding the supernatant. The blank control group was cultured with 10\% FBS-containing DMEM, and the drug group was treated with aqueous solutions of compounds 1-10, with six replicate wells for each concentration. Incubation was continued in $5 \% \mathrm{CO}_{2}$ at $37^{\circ} \mathrm{C}$. After $24 \mathrm{~h}$ of incubation, $10 \mu \mathrm{L}$ of $5 \mathrm{mg} / \mathrm{mL}$ MTT was added to each well. The culture solution was removed after culturing for $4 \mathrm{~h}$. Then, $100 \mu \mathrm{L}$ of DMSO was added to each well, before shaking for $10 \mathrm{~min}$ to achieve complete dissolution. The optical density (OD) was measured at $492 \mathrm{~nm}$ using a microplate reader to calculate cell viability.

\subsection{Anti-Inflammation Assay}

The anti-inflammatory activity of the isolated compounds was evaluated in lipopolysa ccharide-stimulated RAW 264.7 macrophages using the MTT colorimetric method. The 
RAW 264.7 macrophages were seeded in 96-well plates at a density of $1 \times 10^{4}$ cells per well for $24 \mathrm{~h}$, followed by treatment with different extracts of identical purity for another $24 \mathrm{~h}$. The compounds were dissolved in dimethyl sulfoxide (DMSO) and diluted appropriately just before cell treatments. Cells were incubated with the extract at indicated concentrations, with DMSO not exceeding $0.1 \%$ in all experiments. The cells were cultured in DMEM with $10 \%$ FBS and antibiotics (100 U/mL penicillin and $100 \mu \mathrm{g} / \mathrm{mL}$ streptomycin) at $37^{\circ} \mathrm{C}$ with $5 \% \mathrm{CO}_{2}$. NO release was measured as an indicator of the nitrite concentration.

\subsection{Cytotoxicity Test}

The cytotoxic activities of compounds 1-10 against HCT-8 cells were tested using the MTT colorimetric method. HCT-8 cells were cultivated on DMEM medium at $37^{\circ} \mathrm{C}$ and $5 \% \mathrm{CO}_{2}$. After diluting the DMEM medium, cells were seeded into 96-well sterile microplates $\left(6 \times 10^{4}\right.$ cells/well) and cultured with a series of various concentrations of tested compounds or adriamycin (positive control) for $24 \mathrm{~h}$ at $37^{\circ} \mathrm{C}$. After incubation, all compounds were tested at five concentrations $(10-100 \mu \mathrm{M})$ for $1 \mathrm{~h}$. Following this, the supernatant was removed, and all components were dissolved in $100 \%$ DMSO, at such an amount that there was a final DMSO concentration of $0.1 \%$ added to each well. The absorbance was measured using a microplate reader at a wavelength of $570 \mathrm{~nm}$. Data are displayed as the means $\pm S D(n=3)$. The cell growth assay was repeated three times, and the $\mathrm{IC}_{50}$ values were calculated using Microsoft Excel software.

\section{Conclusions}

Nine abietane diterpenoids, including four new ones and one new amide alkaloid, were obtained from the ethnic medicine Nepeta bracteata Benth. for the first time, which clarified the active substances of $N$. bracteata Benth. and laid the foundation for its further clinical application. Furthermore, the anti-inflammatory and cytotoxic activities of all isolates were tested. Compounds 2 and $\mathbf{4}$ displayed potential biological activities with $\mathrm{IC}_{50}$ values of 19.2 and $18.8 \mu \mathrm{M}$ in the anti-inflammation assay and $\mathrm{IC}_{50}$ values of 36.3 and $41.4 \mu \mathrm{M}$ in the cytotoxicity test, respectively. Both compounds are active molecules with potential research value.

Supplementary Materials: Supplementary data associated with this article can be found in the online version.

Author Contributions: L.S., G.M. and J.Z. conceptualized and designed the experiments; M.Z. performed the experiments; M.C. and Y.H. helped with data analysis; C.F. and H.W. helped with structure elucidation. All authors have read and agreed to the published version of the manuscript.

Funding: The work was financially supported by the sub-project of the National Key R\&D Program (2019YFC1712303), the Special Regional Collaborative Innovation Project of Xinjiang Uygur Autonomous Region (2020E01011), and the Major Science and Technology projects of Xinjiang Uygur Autonomous Region (202107638).

Institutional Review Board Statement: Not applicable.

Informed Consent Statement: Not applicable.

Data Availability Statement: The data of the NMR and cellular anti-inflammatory and toxic activity presented in this study are available in supporting information.

Acknowledgments: The authors especially thank Xiaoling Ma for her guidance and help in the process of revising the article.

Conflicts of Interest: The authors declare no conflict of interest.

Sample Availability: Samples of the compounds 1-10 are available from the authors. 


\section{References}

1. Alexander, A.; Maurya, J.; Swarna; Sahu, P.; Sahu, D.; Deshmukh, H. Various aspects of inflammation and the herbal drugs that are used for the treatment of inflammation: An overview. J. Pharm. Res. 2011, 4, 1598-1600.

2. Broz, P.; Dixit, V.M. Inflammasomes: Mechanism of assembly, regulation and sinnalling. Nat. Rev. Immunol. 2016, 16, 407-420. [CrossRef]

3. Lee, K.H.; Kang, T.B. The Molecular Links between Cell Death and Inflmmasome. Cells 2019, 8, 1057. [CrossRef] [PubMed]

4. Mei, Y.; Li, L.; Wang, X.; Zhang, M.; Xu, Y. AGEs induces apoptosis and autophagy via reactive oxygen species in human periodontal ligament cells. J. Cell Biochem. 2019, 121, 1-16. [CrossRef] [PubMed]

5. Marcondes-De-Mello, L.D.F.; Serafim-Costa, M.S.; Alves-E.-Silva, M.M.; Oliveira, N.R.; Chaves, V.E. Effect of glucocorticoids on glyceroneogenesis in adipose tissue: A systematic review. Biochimie 2019, 168, 201-219. [CrossRef] [PubMed]

6. $\quad$ Burnett, C.L.; Bergfeld, W.F.; Belsito, D.V.; Hill, R.A.; Klaassen, C.D.; Liebler, J.G.; Shank, R.C.; Slaga, T.J.; Snyder, P.W. Final report of the safety assessment of kojic acid as used in cosmetics. Int. J. Toxicol. 2010, 29, 187s-213s. [CrossRef] [PubMed]

7. Liu, Y.M.; Yikemu, S.W. Uighur Medical Records; Urumqi Xinjiang People's Publishing House: Urumchi, China, 1999; Volume I, pp. 426-429.

8. Xu, F.; Zhao, J.; He, J. Pharmacognostical identification of Uyghur medicine hard pointed divine herb and its adulterant Schizonepeta tenuifolia. China Pharm. 2012, 23, 3321-3323.

9. Zhang, M.; Ma, X.P.; Ma, D.H. Effect of Uighur Medicine Schizonepeta bracteata total polysaccharide on cytokines in asthmatic rats. J. Immucol. 2012, 28, 222-226.

10. Kalpoutzakis, E.; Aligiannis, N.; Mentis, A.; Mentis, S.; Charvala, C. Composition of the essential oil of two Nepeta species and in vitro evaluation of their activity against Helicobacter pylori. Planta Med. 2001, 67, 880-883. [CrossRef] [PubMed]

11. Milica, G.L.; Miloa, S.; Jelena, V. Antifungalna aktivnost etarskog ulja. J. Serb. Chem. Soc. 2008, 73, 961-965.

12. Miceli, N.; Taviano, M.F.; Giuffrida, D.; Trovato, A.; Tzakou, O.; Galati, E.M. Anti-inflammatory activity of extract and fractions from Nepeta sibthorpii Bentham. J. Ethnopharmacol. 2005, 97, 261-266. [CrossRef] [PubMed]

13. Sy, L.; Brown, G.D. Abietane Diterpenes ftom Illicium angustisepalum. J. Nat. Prod. 1998, 61, 907-912. [CrossRef] [PubMed]

14. Yang, X.W.; Feng, L.; Li, S.M.; Liu, X.H.; Li, Y.L.; Wu, L.; Shen, Y.H.; Tian, J.M.; Zhang, X.; Liu, X.R. Isolation, structure, and bioactivities of abiesadines A-Y, 25 new diterpenes from Abies georgei Orr. Bioorgan Med. Chem. 2010, 18, 744-754. [CrossRef] [PubMed]

15. Fitzgerald, L.J.; Gerkin, R.E. Phenanthrene-9-carboxylic acid. Acta Cryst. 1997, 53, 1265-1267. [CrossRef] [PubMed]

16. Zhang, G.J.; Li, Y.H.; Jiang, J.D.; Yu, S.S.; Qu, J.; Ma, S.G.; Liu, Y.B.; Yu, D.Q. Anti-Coxsackie virus B diterpenes from the roots of Illicium jiadifengpi. Tetrahedron 2013, 69, 1017-1023. [CrossRef]

17. Zhang, G.J.; Li, Y.H.; Jiang, J.D.; Yu, S.S.; Wang, X.J.; Zhuang, P.Y.; Zhang, Y.; Qu, J.; Ma, S.G.; Li, Y. Diterpenes and sesquiterpenes with anti-Coxsackie virus B3 activity from the stems of Illicium jiadifengpi. Tetrahedron 2014, 70, 4494-4499. [CrossRef]

18. Shackelford, R.E.; Alford, P.B.; Xue, Y.; Thai, S.F.; Pizzo, S. Aspirin Inhibits Tumor Necrosis Factor- $\alpha$ Gene Expression in Murine Tissue Macrophages. Mol. Pharm. 1997, 52, 421-429. [CrossRef] [PubMed]

19. Grosser, N.; Schroder, H. Aspirin Protect Endothelial Cells from Oxidant Damage Via the Nitric Oxide-cFMP Pathway. Arterioscler. Thromb. Vasc. Biol. 2003, 23, 1345-1351. [CrossRef] [PubMed]

20. Jing, W.; Li, F.S.; Pang, N.N.; Tian, G.; Jiang, M.; Zhang, H.P.; Ding, J.B. Inhibition of Asthma in OVA Sensitized Mice Model by a Traditional Uygur Herb Nepeta bracteata Benth. Evid. -Based Complementary Altern. Med. 2016, 2016, 1-8. [CrossRef] [PubMed]

21. Hajiheydari, M.R.; Yarmohammadi, M.E.; Izadi, P.; Jafari, F.; Naseri, M. Effect of Nepeta bracteata Benth. On allergic rhinitis symptoms: A randomized double-blind clinical trial. J. Res. Med. Sci. 2017, 22, 1-6. 